INTERNATIONAL JOURNAL OF

MULTIDISCIPLINARY STUDIES IN ART AND

TECHNOLOGY

ISSN: $2735-4342$

VOLUME 4, ISSUE 1, 2021, 27 - 48.

www.egyptfuture.org/ojs/

\title{
The Role of Technology in Providing Graphic Treatments for The Introductions of Egyptian Drama Television Series
}

\author{
Esraa Wagih Ahmed Ahmed Abd Elawy \\ Assistant Lecturer at the Faculty of Fine Arts, Graphic Department \\ Email:esraa.wagih.1993@gmail.com
}

\begin{abstract}
This research Take up the development of the introductions of the Egyptian television series in the eighties to the stage of digital technology, and the emergence of modern techniques, methods and graphic visual effects, to give a graphic value that expresses the dramatic, and be It is like the window that overlooks this work, which has become an art in itself, that is prepared separately and carefully.

The study summarized: an attempt to understand and explain the visual language used in the design of the introductions, by providing an analytical study of a number of models for the introductions, the role of technology in graphic processing, and the extent of diversity caused by the development of the use of digital technology in the treatment of the introductions of the Egyptian television series.

The researcher recommends: inviting the institutions concerned with teaching this field, inviting cultural and artistic institutions to sponsor and interest in this art and on television, and allocate budgets from the state and incentive awards for makers of television introductions.
\end{abstract}

\section{KEYWORDS}

Design of TV introductions - Graphic effects - Digital technology-Drama Series

\section{INTRODUCTION:}

With the intensification of foreign competition and the invasion of dramas coming from overseas, The Arab spectator has become more demanding than before and is able to draw comparisons that affect all components of the dramatic work, including the introduction to the dramatic work, which is linked to the identity of the dramatic work, This prompted some of the new Arab drama makers to try to pay attention to and develop the design of the introductions and begin to formulate the visual language in an artistic way, as the viewer has become following visual formulas when watching TV ( Martin, Marcel, 2017). 


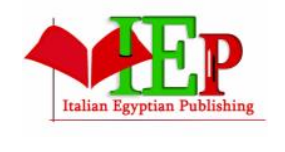

ISSN: 2735-4342
INTERNATIONAL JOURNAL OF

MULTIDISCIPLINARY STUDIES IN ART AND

TECHNOLOGY

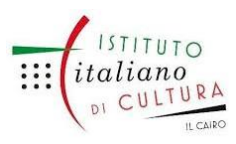

www.egyptfuture.org/ojs/

There can be no dramatic or even cinematic work without an introductory introduction that leads us to know the title of the subject being presented, It reflects the visual language of the work. This matter has become a given, It must be started and cannot be overcome, and the idea of making introductions has evolved, becoming not just identification cards for the dramatic work, Rather, it has become a dramatic philosophy and an issue that must be studied and taken care of, so we find for each series its own way of investing the introduction, so we find some introductions presented in a normal way, just names that float on the screen and then disappear, while there are other introductions that are given an artistic dimension and interest.

The visual language and graphic processors help the viewer to impart a visual state and its coexistence in a certain historical period, Through the creative harmony between the artistic form and the intellectual content, as technological development contributed to making the introductions a field for competition (Gamal, Kawas,2014)

Since the identity of the series is always linked to its introduction, images, lighting, movement, sound and graphic processors remain for long periods of time in the viewer's memory, with the aesthetic values they carry, The confirmation remains that the design of the introductions is currently Facing a great development at the level of the Arab world, a development that indicates the desire of workers in this field to improve the dramatic product, and to present valuable artistic works in respect of the mentality and taste of the Arab viewer (Melis,I,2007).

\section{1-1 The beginning of appearance of the Egyptian TV introductions}

With the beginning of the sixties of the last century, and the start of television broadcasting in Egypt; Dramas began to appear, the introductions were not the focus of attention at that period, and thinking about them was started after the work was finished completely, The introductions appeared in the beginning as a form of the introductory title, in preparation for the start of the drama, to perform a basic function, which is the definition of the work and those in charge of it, as it relied on the news value in the first place, as it was silent without any voices 


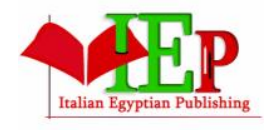

ISSN: $2735-4342$
INTERNATIONAL JOURNAL OF

MULTIDISCIPLINARY STUDIES IN ART AND

TECHNOLOGY

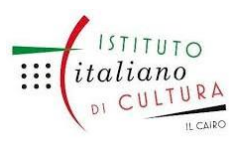

www.egyptfuture.org/ojs/

The television in its beginning broadcasted its image in black and white, there was no space available for innovation, and the introductions represented writings such as its cinematic beginning written by calligraphers, as the television studios hired crews of calligraphers who designed and executed the introductions of the films; They used to implement them manually in the form of cards made of cardboard, boards, ribbons, or on decoration walls, where their signatures appeared on the cards as in fig.1(Lila, Abou Lughod, 2005).

The cards were shown in front of the camera in a succession, and some directors used many types of tricks in moving the camera in front of the address cards to suggest some kind of movement, but they remained only fixed cards; Since it initially relied on non-specialists in the implementation process; As a result, the introductions lack many aesthetic and artistic values because they are confined to limited forms of designs, Where the graphic design of the introductions in the 1960s was characterized by bold lines and raised typography, great contrast in lightness and distance from details(Gamal, kawas,2014)
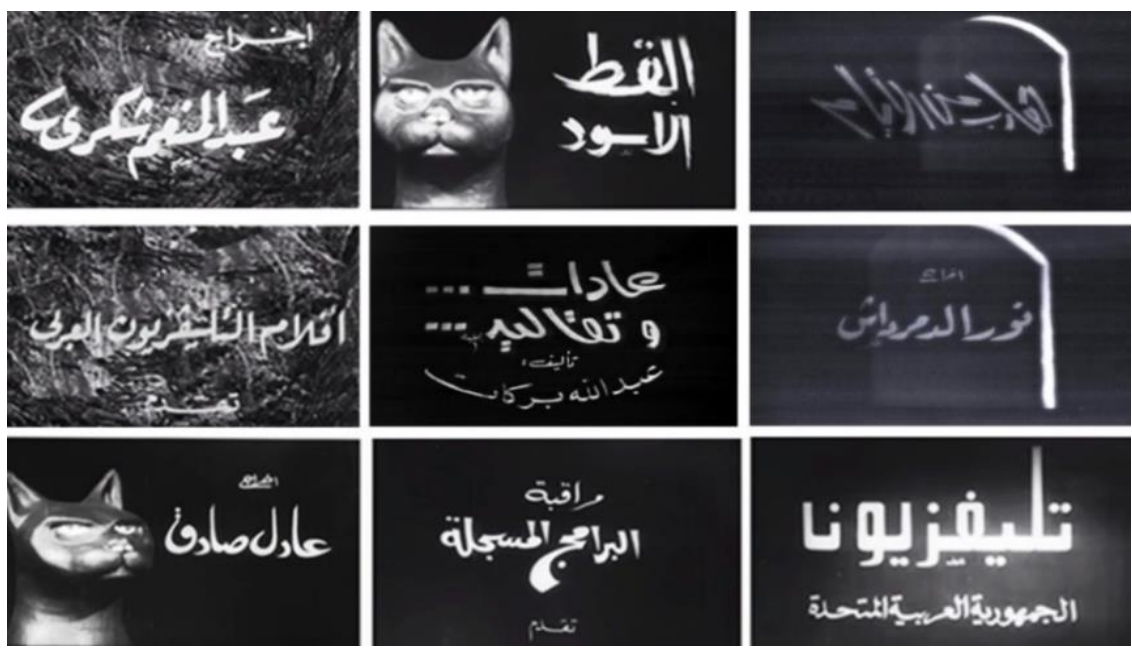
Many of the Introduction designers appeared in that period, most notably the head of the Egyptian Calligraphers Syndicate, Musaad Khudair, the famous khudir Al-Borsaidi (1942 AD), who joined Egyptian television in 1964, There is also the calligrapher and the designer of the introductions al-Shahri (1942-2004 AD), who designed nearly 600 introductions for a film and television, as his production appeared in the seventies and eighties, and the calligrapher Sayed Gad, Qarsham, Al-Sufi, Fikri Ashour ... and many others, whose names appeared with a signature appended to the calligrapher. His writings, either on the first title or the last title in the introduction, as in Fig.2 (Al-Amili\& Hussein, Shatha...,2013).

Fig.1 showing the design of introductions series at the beginning of the Egyptian television broadcast in the 1960s
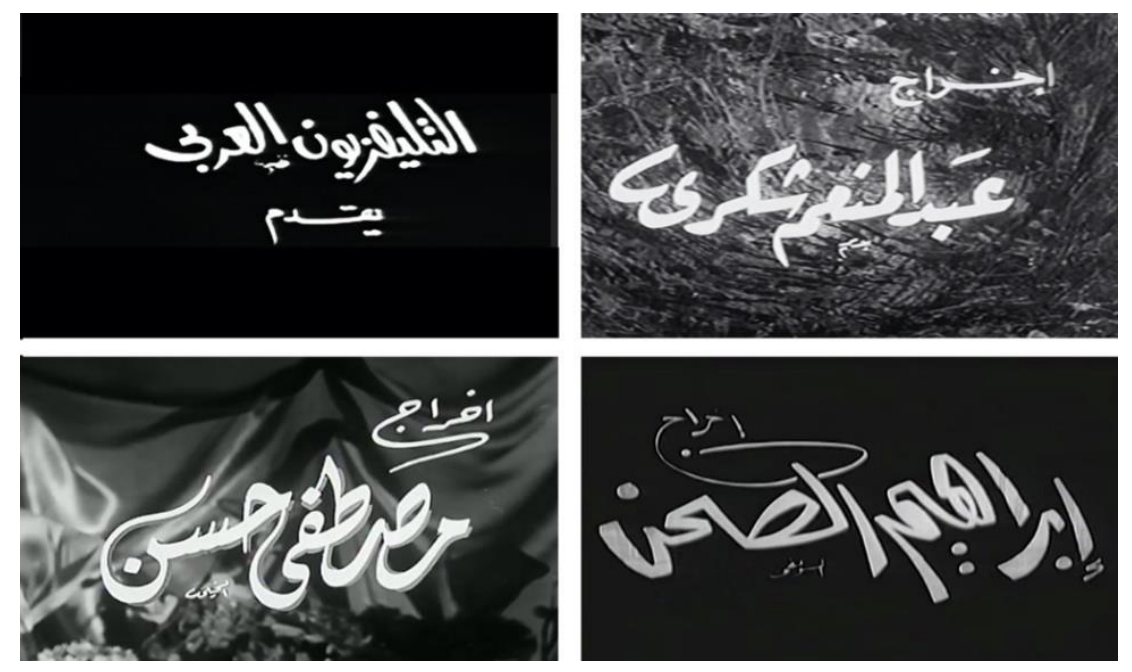

Fig.2 shows the signatures of calligraphers manually in television introductions

\section{1-2 The Historical Development of The Egyptian Television Introductions}

\section{1-2-1 Development in terms of presentation and implementation methods}

First: the mechanical stage 


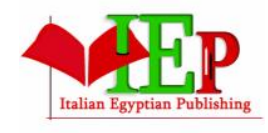

ISSN: $2735-4342$
INTERNATIONAL JOURNAL OF

MULTIDISCIPLINARY STUDIES IN ART AND

TECHNOLOGY

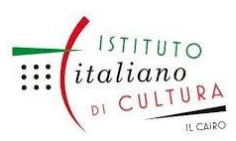

www.egyptfuture.org/ojs/

The methods varied at that stage in terms of implementation and methods of presenting introductions. Before digital technology, introductions were executed manually through drawing and hollow cardboard windows and dealing with the camera mechanically according to what serves the idea. The introductions at the first glance were cards from fixed addresses as mentioned earlier, The artistic methods of displaying them also varied, and these methods seemed primitive, and had many technical problems. Sometimes the picture appeared shaky, sometimes there were some letters incomplete or cut off, and sometimes the design was not clearly recorded on the screen or it was not suitable for the subject of the television series, and these are some primitive means. Which used to implement the television introductions (Yael\&Bill,2012).

\section{1-2-1-1 Stand}

The cards are placed on a stand that resembles a musical note holder, opposite the camera in a fixed shape, and the studio director takes over the change of cards in front of the camera lens as shown in Fig.3 (Saeed, Manar,2002).

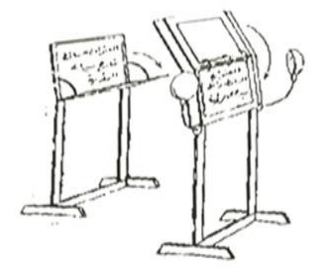

\section{1-2-1-2 Flapper}

Fig. 3 shows the shape of the holder that was used to display the cards

It is a type of holder in which the cards are punched and then installed in two rings, and it was used when there are many cards that should be displayed in the foreground, and this method leads to a rapid change in their width in successive intervals, as in Fig.4.

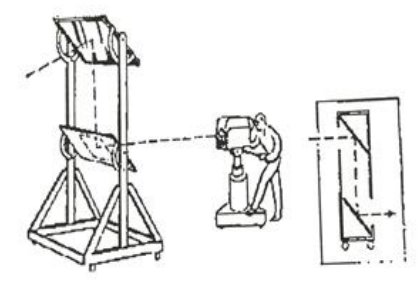

Fig.4 shows the shape of the flipchart that was used to display cards 


\section{1-2-1-3 Windmill}

A model for rapid change, as this method relies on installing four panels, and these panels can be changed by turning through a windmill, as their energy was sometimes changed in front of the camera through the appearance of hands that flipped the cards, as this method was used in the past in the introductions of films as in the fig.5.

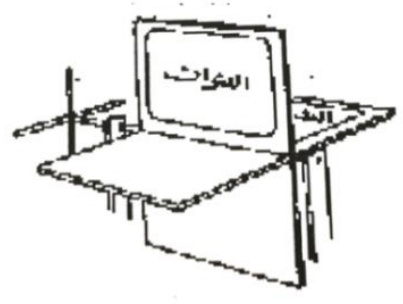

Fig.5 shows the windmill used to display the cards

\section{1-2-1-1-4 Long Banner}

A form of fixed introductions, which are cards or cardboard that are placed horizontally next to each other so that it represents a long banner, then the camera moves horizontally to display them in succession from one card to another, so that in this way it is taken into account to move the camera through its holder, so if the camera moves while it is in place It results in a distortion called (keyhole distortion) where the side closest to the camera appears larger than the other side according to the movement of the Mohamed ,2001).
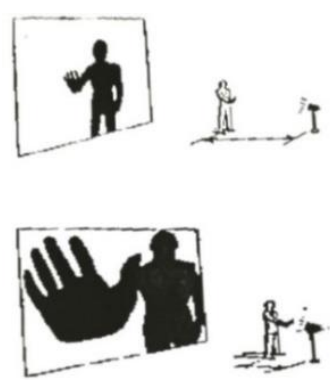

camera, as shown in Fig.6 (Ashraf,

Fig.6 shows the long banner and keyhole distortion caused by the movement of the camera in place without a stand during photography

\section{1-2-1-5 Cards}


It is a piece of cardboard on which the data to be displayed is written or drawn, and it is displayed by a device located in the display unit, and these cards have a specific size 4X5 inches, and when preparing these cards, the information and important design parts in the telematics area should be in an area of dimensions $24 \mathrm{X}$ Inch, taking into account the safety zone as shown in Fig.7, This method is used when more than one visual element should be displayed on one card, such as the channel logo, writings and photographs, and this was one of the most used methods for displaying static introductions (Inman\& Smith,2006) .

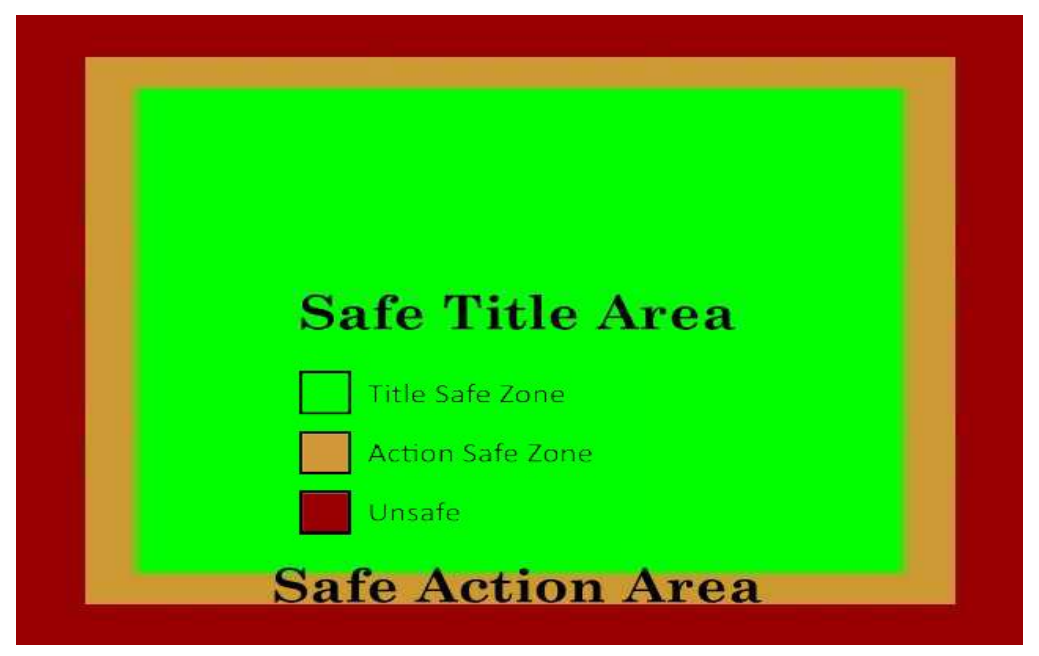

Fig.7 shows the safety zone in the TV scan

\section{Second: The electronic stage}

\section{1-2-1-2-1 Analog System}


The development at this stage began with development in the field of television, and among the first developments in which technology changed the way it transmits image and sound was the emergence of the analog or analog system, which is a common electronic system that has become common in the field of media such as radio, television and tape recorders, This system is characterized by that it records the image and sound signals, re-broadcasts and displays them on various and all television sets through magnetic tapes, and this system is often dealt with through electromagnetic signals that are not subject to physical damage (Wang,Y,2003).

\section{1-2-1-2-2- Digital System}

Television introductions and their traditional means have been replaced by advanced ones through digital technology, which is represented by the conversion of signals from analog to digital, and the development of computers and its programs have affected the shape and structure of television introductions, The digital devices that helped implement introductions such as the Character Generator and the Digital Paint System, where lines and drawings are executed and manipulated in terms of color, size, movement and lighting, are stored and retrieved completely electronically (Fathi, Lia, 2018).

\section{1-2-2 Development in terms of design}

\section{1-2-2-1 The 1980S (1980-1989)}

This period was marked by the beginning of the emergence of television graphics, as digital technologies were introduced in the late eighties and early nineties of the twentieth century in order to process text, images and sound, so the use of pens, electronic brushes and sound effects also appeared in two types of programs known as GUI, which is an abbreviation for Graphic User Interface, which depends on the use of graphics and menus. The tests, with which, any artwork can be produced from the computer directly on the screen and combined with text and sound, which led to the remarkable development in the design of the introductions and their transition from the most stable and rigid form to the most mobile (Inceer,2007). 


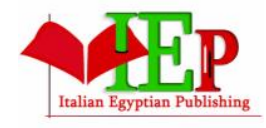

ISSN: $2735-4342$
INTERNATIONAL JOURNAL OF

MULTIDISCIPLINARY STUDIES IN ART AND

TECHNOLOGY

VOLUME 4, ISSUE 1, 2021, $27-48$.

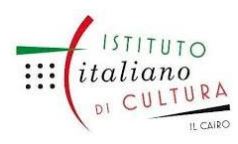

www.egyptfuture.org/ojs/

Despite the technical development in Thies field, the introductions are still based on writings in the hands of calligraphers, with the use of simple drawings inspired by the content of the series. Collage formations, photographs and drawings also played an important role, the introduction lengthened sometimes reaching 6 minutes, This period was also the beginning of the emergence of graphic effects and tricks, as in the fictional series (One Thousand and One Nights) produced in 1985, in which many graphic-visual tricks appeared as in fig.9.

\section{Models of introductions $1950 \mathrm{~S}$}

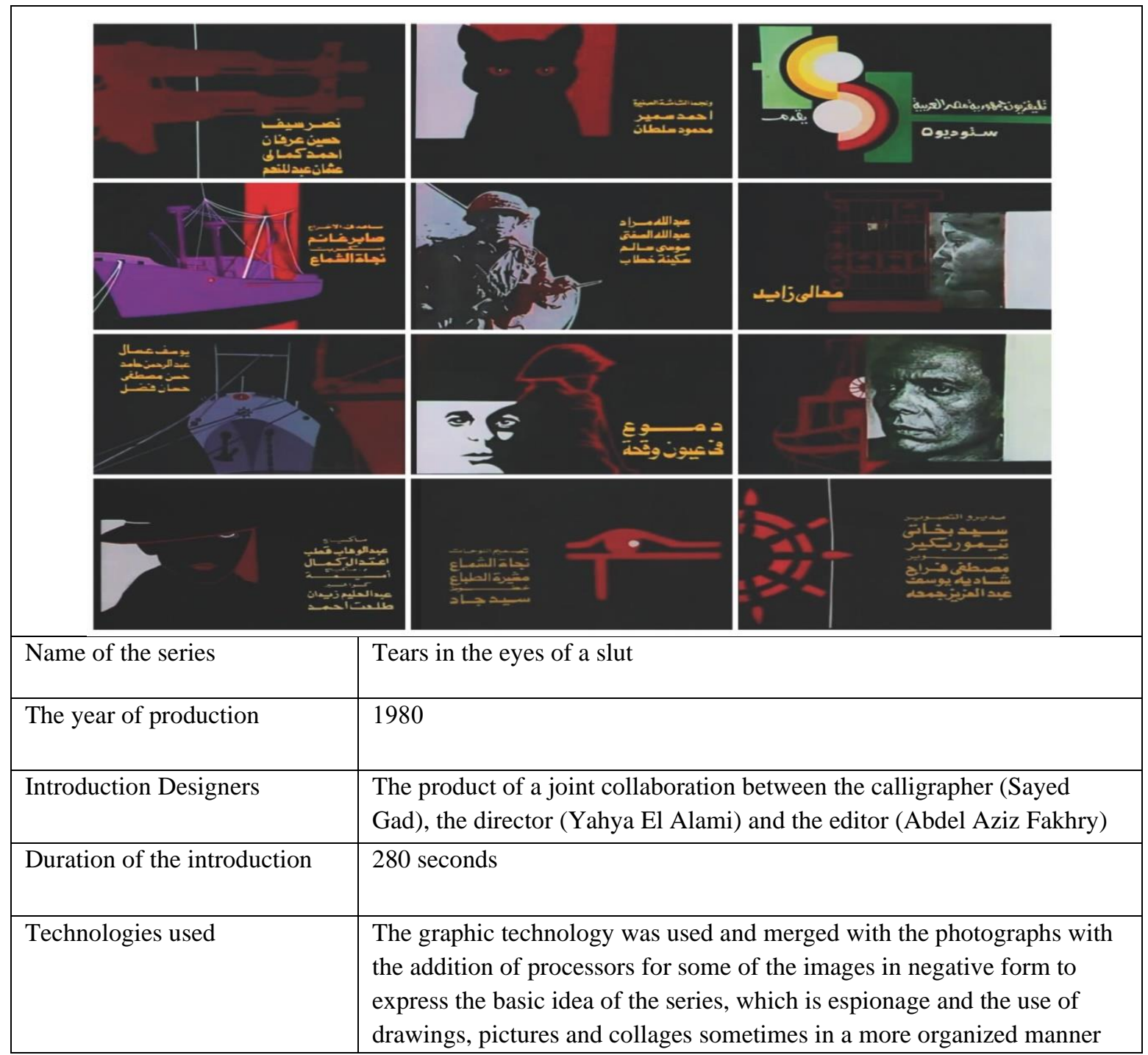




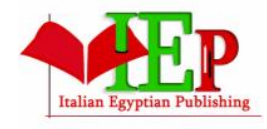

ISSN: $2735-4342$
INTERNATIONAL JOURNAL OF

MULTIDISCIPLINARY STUDIES IN ART AND

TECHNOLOGY

VOLUME 4, ISSUE 1, 2021, 27 - 48.

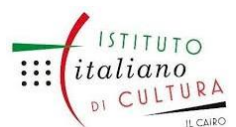

www.egyptfuture.org/ojs/

\begin{tabular}{|l|l|}
\hline & with writings contrasting color with the background \\
\hline Design Elements & Typography, color and graphics \\
\hline
\end{tabular}

Fig.8 An analytical model for the Introduction of the series (Tears in Brazen Eyes), produced in 1980

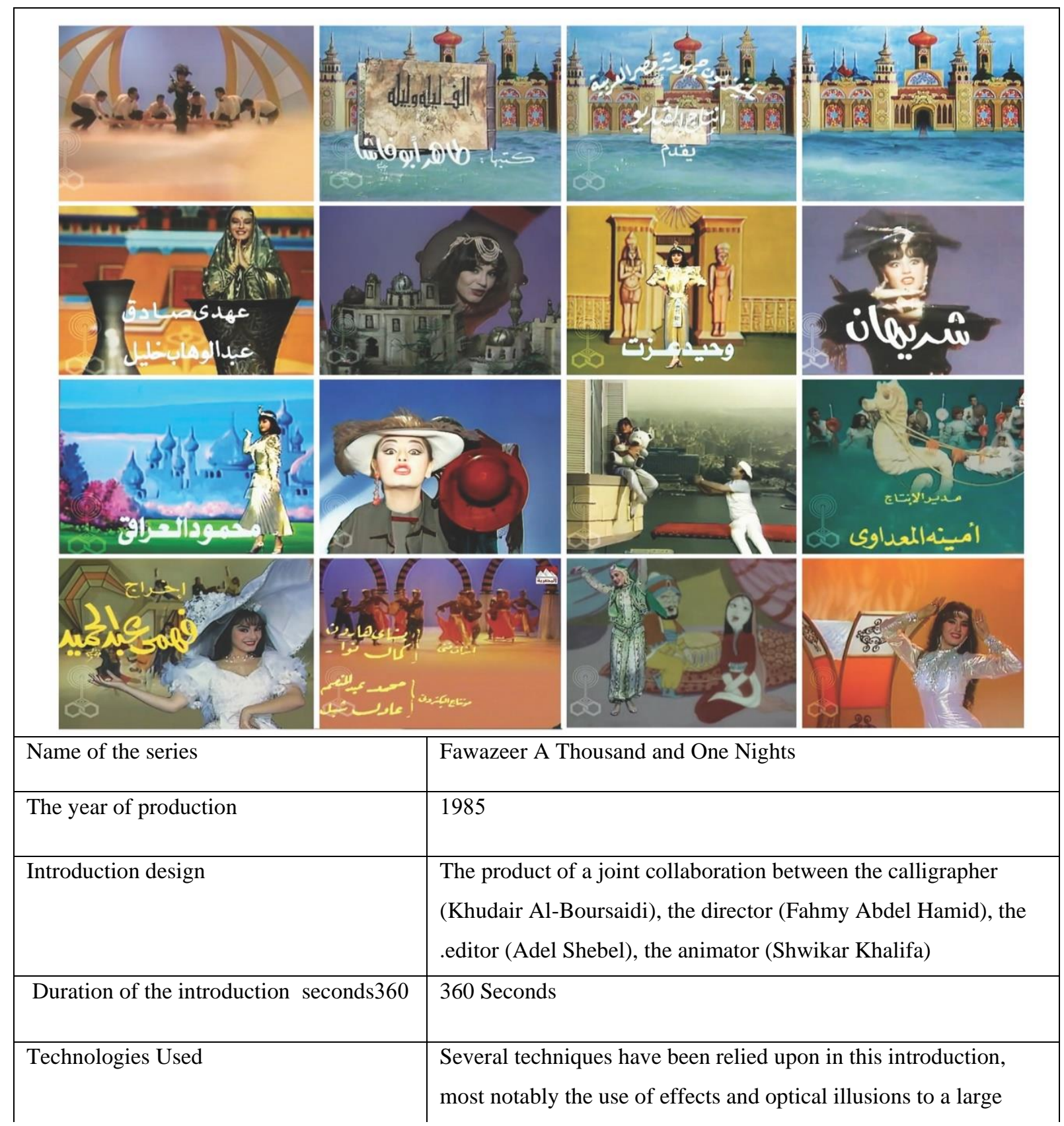


INTERNATIONAL JOURNAL OF

MULTIDISCIPLINARY STUDIES IN ART AND

TECHNOLOGY

ISSN: $2735-4342$

VOLUME 4, ISSUE 1, 2021, $27-48$.

www.egyptfuture.org/ojs/

\begin{tabular}{|l|l|}
\hline & $\begin{array}{l}\text { extent, as animation has been integrated with photographs and } \\
\text { live photography (video) }\end{array}$ \\
\hline Design Elements & $\begin{array}{l}\text { Arabic calligraphy, drawings, photographs and live photography } \\
\text { (video) }\end{array}$ \\
\hline
\end{tabular}

Fig.9 An analytical model for the introduction to the Fawazir series One Thousand and One Nights (Fawazir A Thousand and One Nights) produced in 1985 AD and the beginning of the introduction of optical illusions on the introductions

\section{1-2-2-2 The 1990s (1990-1999)}

This stage witnessed the emergence of many television series, and thus the emergence of television introductions implemented with digital technology in a larger and different manner than before, as digital technology allowed the collection of simple movements with an ability that exceeds the previous stages, And since digital systems are the most recent developments in the design of television introductions in that period; Because of its possibility of making montage and adding new transitional effects, in that period the reliance on computer graphics began as a basic means of implementation, so the interest in that period was more technical methods and methods of implementation than the design aspect, so the greater interest was towards the use of transitional and visual effects and adding Simple color treatments ... and other treatments.

The introductions appeared in that period in their primitive form, and the design was predominantly concerned with the news value (headlines and names of those in charge) more than the artistic value. Some of the introductions are shots of the actors' faces, cut with a very primitive, unprofessional, repetitive, and compact cut without taking into account the technical aspect, due to the beginning of the use of television graphics technology.

At this stage, lyrical introductions have spread alongside music, and the introductions have witnessed intense competition of a special kind between singing stars in Egypt and the Arab world, and simple color processors have also been used in a more innovative way before, and the introductions have remained on this design approach, but in a more sophisticated and creative way until The first beginnings of the 21 st century, In view of the technical development in the art 


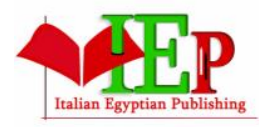

ISSN: $2735-4342$
INTERNATIONAL JOURNAL OF

MULTIDISCIPLINARY STUDIES IN ART AND

TECHNOLOGY

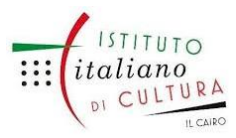

www.egyptfuture.org/ojs/

of television graphics and montage; This led to the emergence of the names of the introductions designers, the names of those who do the montage of the introductions, and other people responsible for implementing the tricks and influences in the introductions and the calligraphers who implement the titles and the names of those in charge of the work, so there are many specializations for artistic production of television introductions.

\section{Models introductions 1990s}
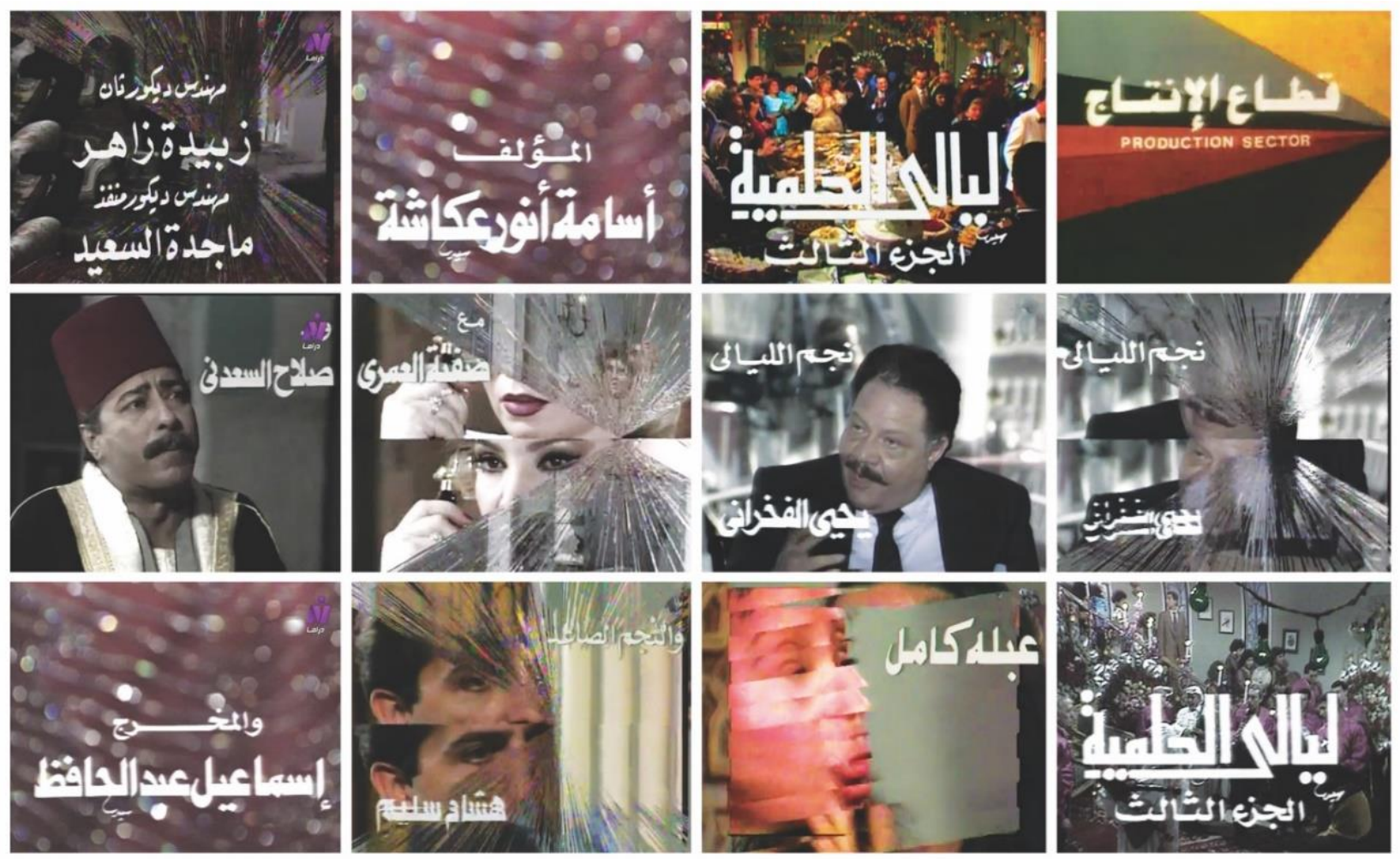

Name of the Series

Layali elhelmya 3 


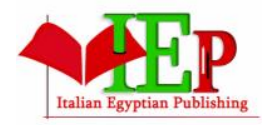

ISSN: $2735-4342$
INTERNATIONAL JOURNAL OF

MULTIDISCIPLINARY STUDIES IN ART AND

TECHNOLOGY

VOLUME 4, ISSUE 1, 2021, 27 - 48.

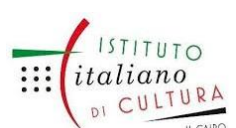

www.egyptfuture.org/ojs/

\begin{tabular}{|l|l|}
\hline The year of production & 1990 \\
\hline Introduction Design & $\begin{array}{l}\text { The designer of the introduction, director (Mohamed Gharib) and editor } \\
\text { (Osama El-Gamal) with the participation of the calligrapher (Sayed } \\
\text { Gad) }\end{array}$ \\
\hline Seconds Duration of the Introduction & 285 Seconds \\
\hline Technologies Used & $\begin{array}{l}\text { Much reliance has been placed on the use of different transition effects } \\
\text { to move from one frame to another or from one scene to another, as well } \\
\text { as the use of color processors for images }\end{array}$ \\
\hline Design Elements & Typography, photography and live photography (video) \\
\hline
\end{tabular}

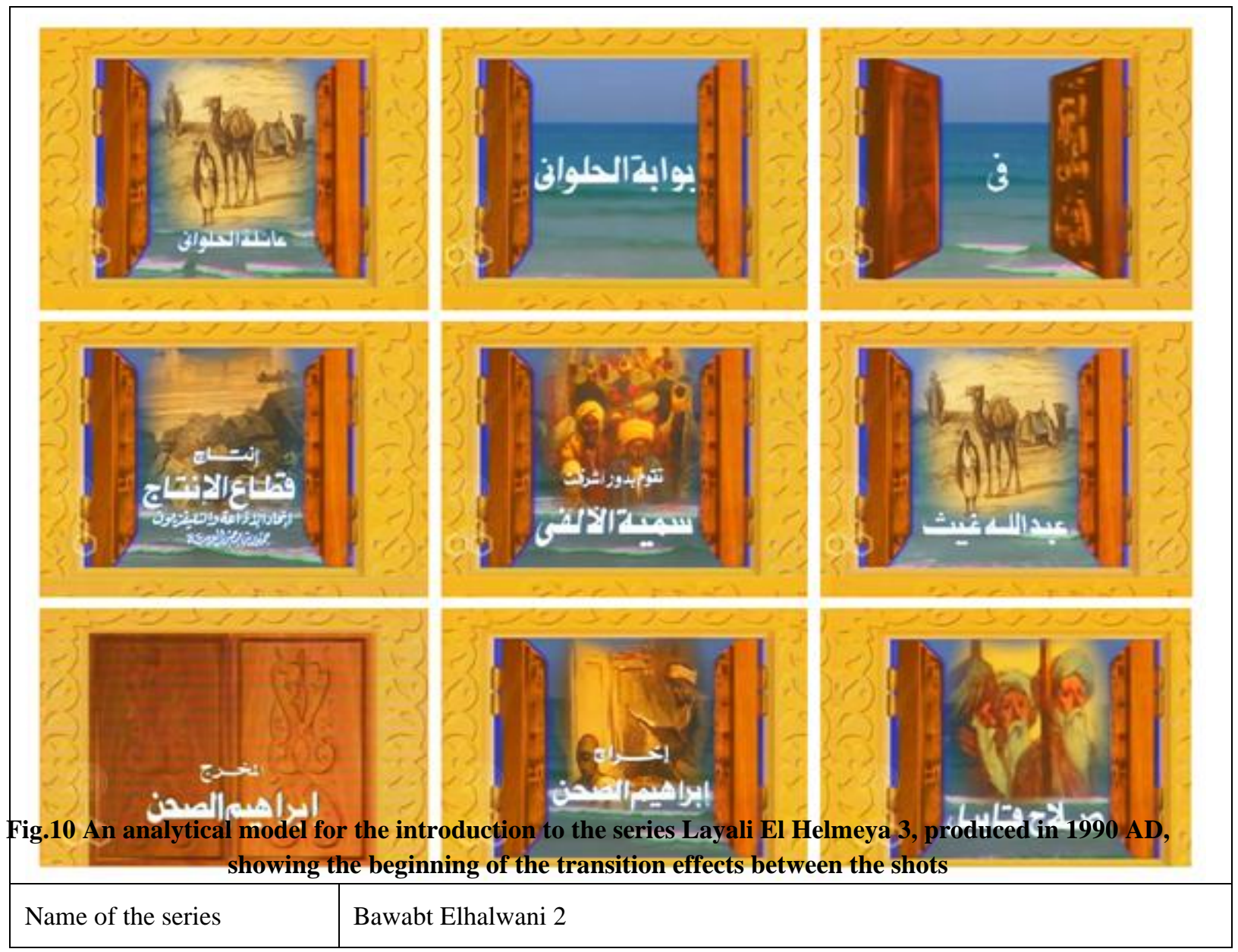


INTERNATIONAL JOURNAL OF

MULTIDISCIPLINARY STUDIES IN ART AND

TECHNOLOGY

ISSN: $2735-4342$

VOLUME 4, ISSUE 1, 2021, $27-48$.

www.egyptfuture.org/ojs/

\begin{tabular}{|l|l|}
\hline The year of production & 1994 \\
\hline Introduction design & Introduction (Shwikar Khalifa) and Editor (Medhat Bahjat) \\
\hline Duration of the introduction & 249 Seconds \\
\hline Technologies used & $\begin{array}{l}\text { A fixed scene was adopted for a closed gate at the beginning of the foreground } \\
\text { surrounded by decorations, then the gate opened and through it were shown } \\
\text { cropped portions of illustrations and combined with the animated background of } \\
\text { a beach and the writings mount on it }\end{array}$ \\
\hline Design Elements & \begin{tabular}{l} 
Typography, photos, drawings and live photography (video) \\
\hline
\end{tabular}
\end{tabular}

Fig.11 An analytical model a series Introduction (Bawabt Elhalwani 2), produced in 1994 AD

\section{1-2-2-2 Modern period (2000-2020 AD)}

The introductions to the same approach continued in the methods of typical processors in the eighties and nineties of the twentieth century and the beginning of the twenty-first century, until a great development occurred due to the use of digital computer technology, which worked to abolish writing by calligraphers and make writings completely digital, so the introduction of computer graphics and visual illusions In the introductions industry, a boom has occurred in the manufacture of introductions and processing methods, which helped create a form and content for the introductions from a technical point of view, whose quality and idea differ according to the quality of the presented artwork.

At the beginning of the 2000s, television introductions took a fixed form, which is the use of scenes from within the series, truncating and using them in the introductions with the emergence of the names of the actors. They sometimes appear in $2 \mathrm{D}$ and $3 \mathrm{D}$, and this shape remained stable during the first decade of the 2000s. 
The introductions began to develop rapidly and creatively in the second decade of the 2000s, as it used two-dimensional and three-dimensional animation, which added a distinct artistic and innovative character, and computer graphics entered more innovatively in implementation and processing methods and allowed shapes to be combined with images, backgrounds and color processors in a more innovative way. The introductions have a technical and aesthetic function in addition to their news function, so digital technology has saved us a lot of time and money.

During the second decade of the 2000s, the introductions appeared at this stage in a different artistic way than before, as the introductions began to pay more attention to their artistic value than to the news value (names and addresses), The writings also appeared in different sizes and shapes of letters that were proportional to the size of the screen and in contrasting colors integrated with their backgrounds in a coherent manner, as the graphic elements varied from pictures, drawings, shapes, writings and colors in addition to the special effects that did not exist before, so the introductions began to take other artistic forms After that, it developed rapidly and creatively, as it used 2D and 3D animation, which added a distinct artistic and innovative character to it.

\section{Introductions of The Modern Period}




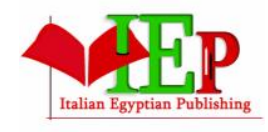

ISSN: $2735-4342$
INTERNATIONAL JOURNAL OF

MULTIDISCIPLINARY STUDIES IN ART AND

TECHNOLOGY

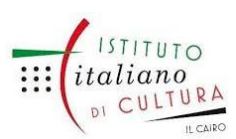

www.egyptfuture.org/ojs/
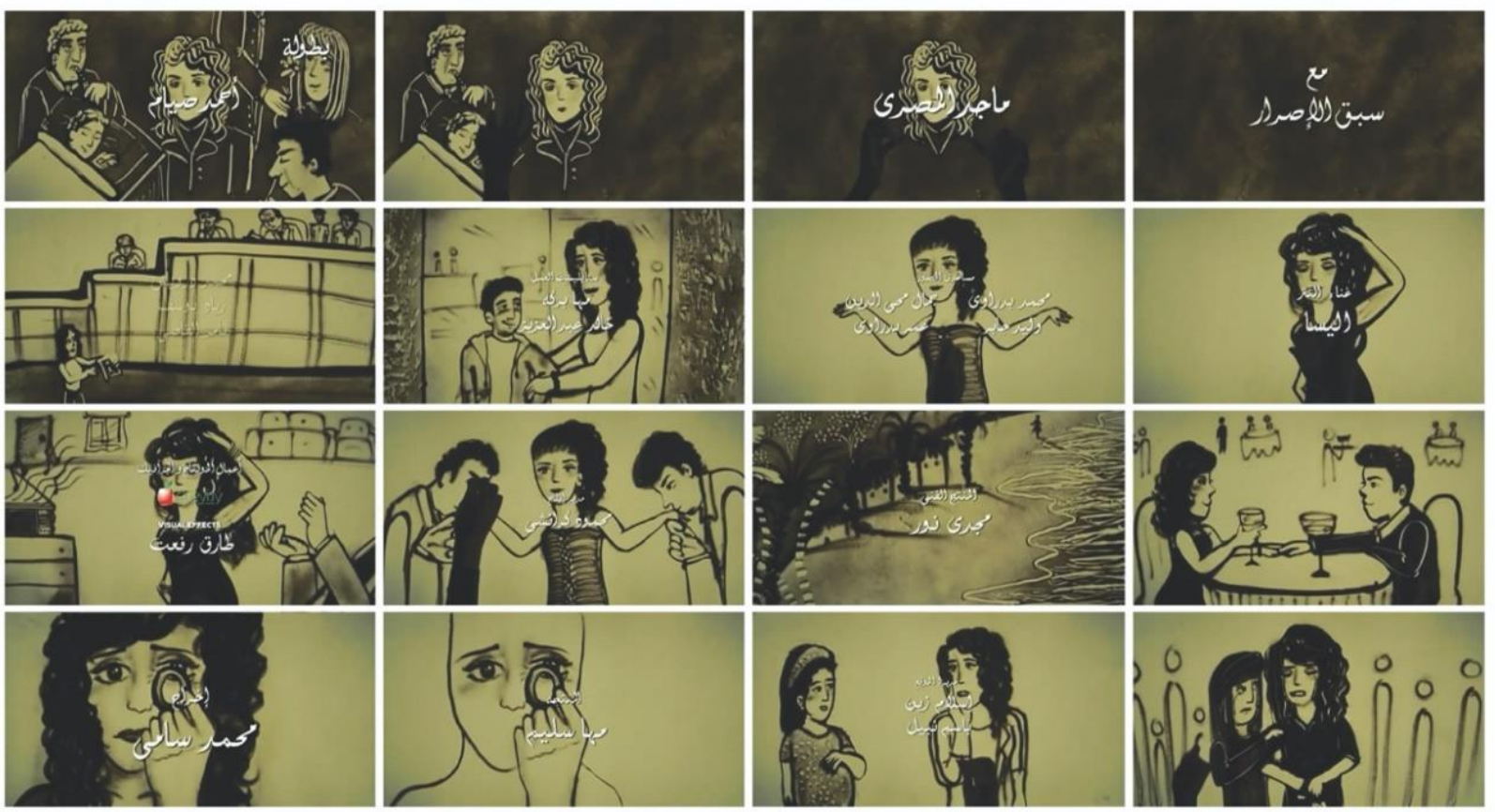

\begin{tabular}{|l|l|}
\hline Name of the series & Maa sabq el esrar \\
\hline The year of production & 2012 \\
\hline Introduction design & $\begin{array}{l}\text { Intro Designer - Sand Painting (Shaima Al-Mughairy) Monteer (Hazem } \\
\text { Samir) }\end{array}$ \\
\hline Duration of the introduction & 252 Second \\
\hline Technologies used & $\begin{array}{l}\text { Here we rely on the implementation of the introductions using comics art, } \\
\text { using a different medium, which is drawing with sand on a glass surface } \\
\text { in a completely manual manner, using addition and deletion to contrast } \\
\text { the drawings with the background, in addition to the used color identity } \\
\text { that matches the dramatic situation of the series }\end{array}$ \\
\hline Design Elements & Graphics and typography \\
\hline
\end{tabular}

Fig.12 An analytical model from the introduction to the series (Premeditated), produced in 2012, which illustrates the use of drawings using sand 


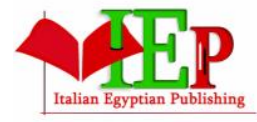

ISSN: $2735-4342$
INTERNATIONAL JOURNAL OF

MULTIDISCIPLINARY STUDIES IN ART AND

TECHNOLOGY

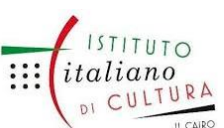

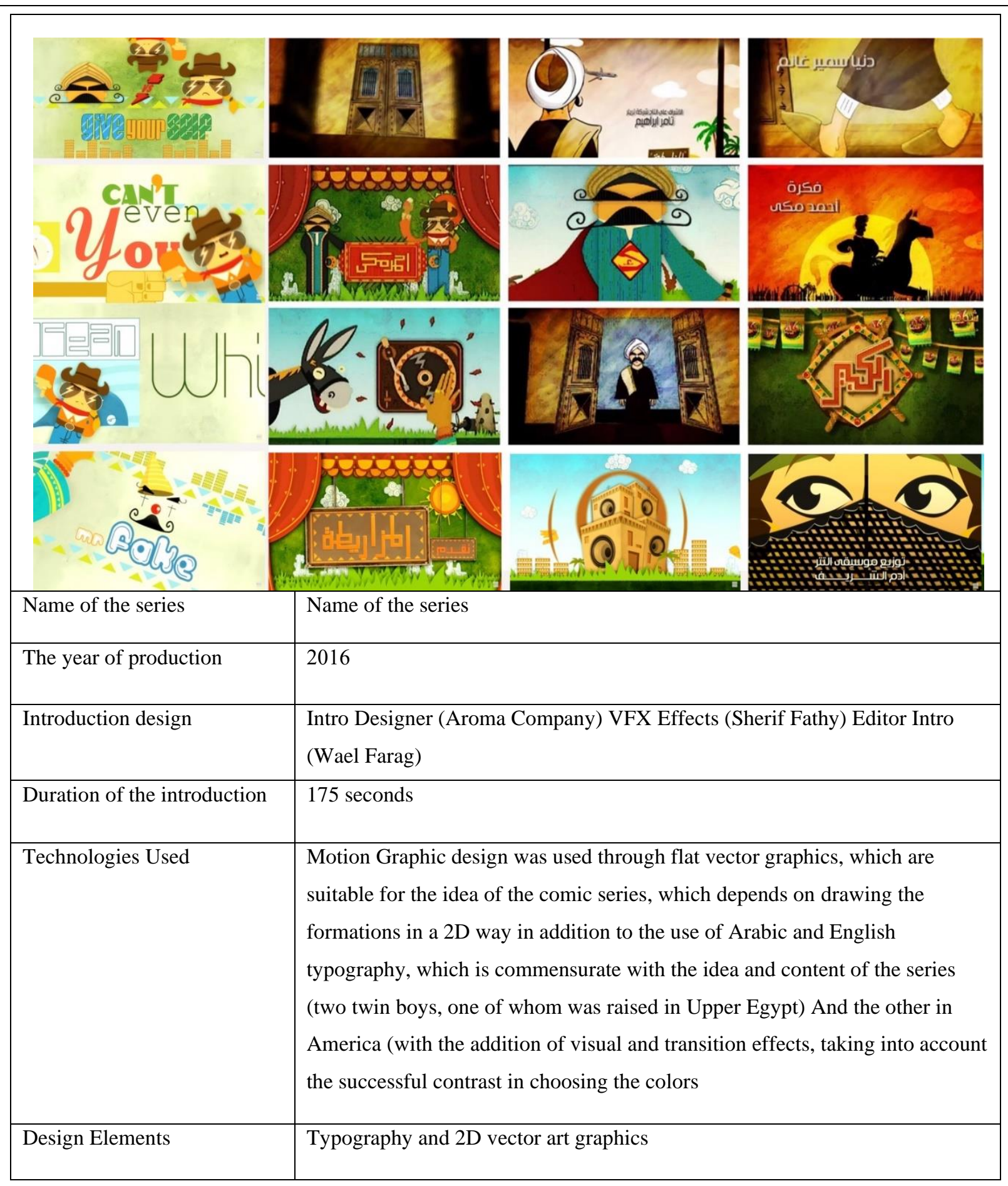

Fig.13 An analytical model from the series (Al-Kabeer Away), produced in 2016 AD 


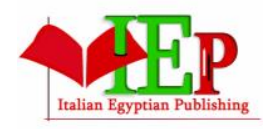

ISSN: $2735-4342$
INTERNATIONAL JOURNAL OF

MULTIDISCIPLINARY STUDIES IN ART AND

TECHNOLOGY

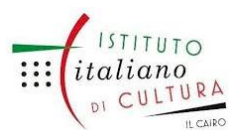

www.egyptfuture.org/ojs/
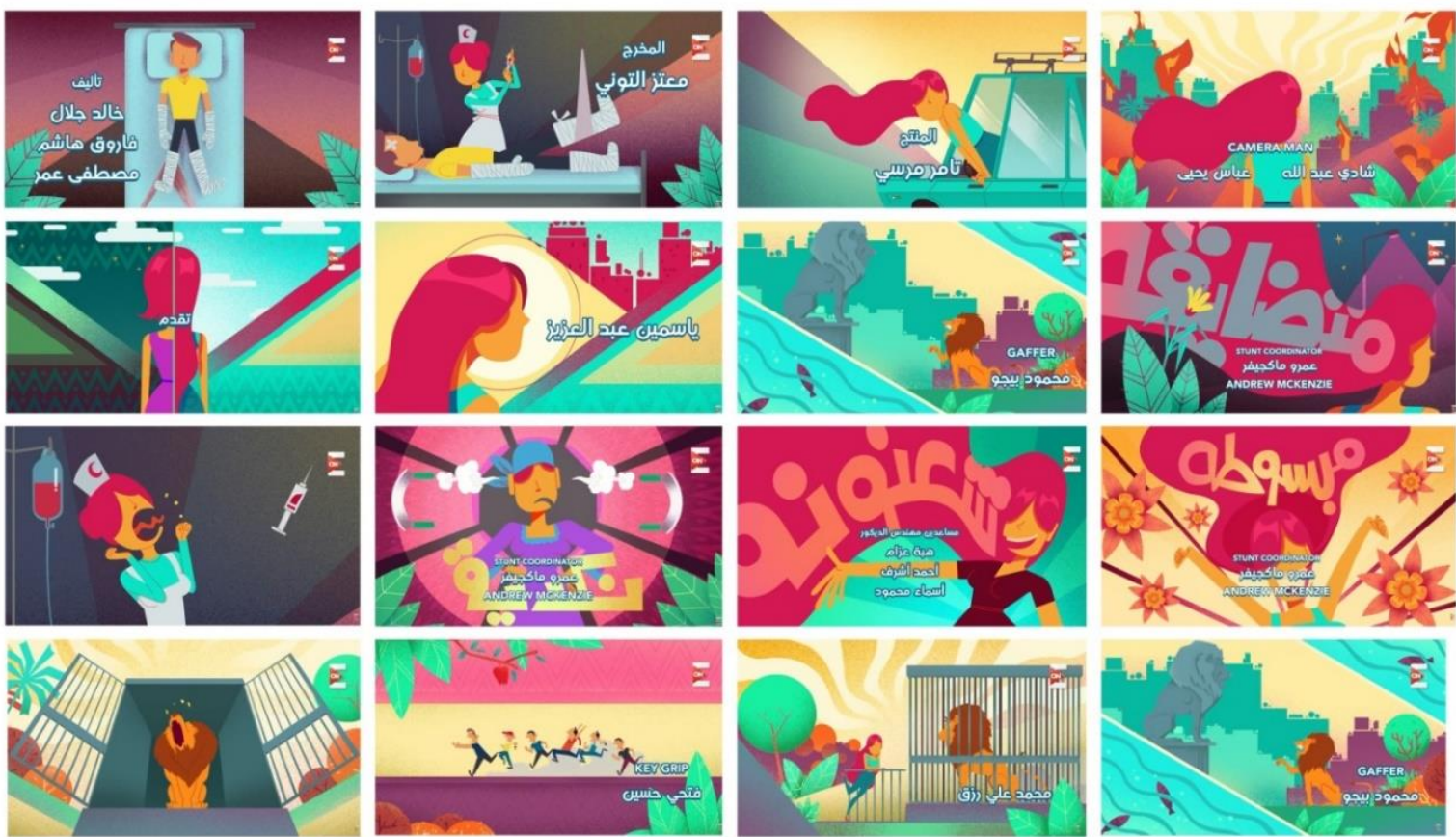

\begin{tabular}{|l|l|}
\hline Name of the series & (Harbana Minha) \\
\hline The year of production & 2017 \\
\hline Introduction design & $\begin{array}{l}\text { Intro Designer (Follk Company) VFX Effects (Ahmad Al-Canvas) Editor- } \\
\text { in-Chief (Sulafa Noureddine) }\end{array}$ \\
\hline Duration of the introduction & 215 seconds \\
\hline Technologies used & $\begin{array}{l}\text { Motion Graphic design was used through flat vector graphics, which are } \\
\text { suitable for the idea of the comic series, which depends on drawing } \\
\text { elements in a 2D way with the addition of some visual and transition } \\
\text { effects, taking into account the contrast in colors }\end{array}$ \\
\hline Design Elements & \begin{tabular}{l} 
Typography and 2D vector art graphics \\
\hline
\end{tabular} \\
\hline
\end{tabular}

Fig.14 An analytical model from the series (Harbana Minha) produced in 2017 AD 


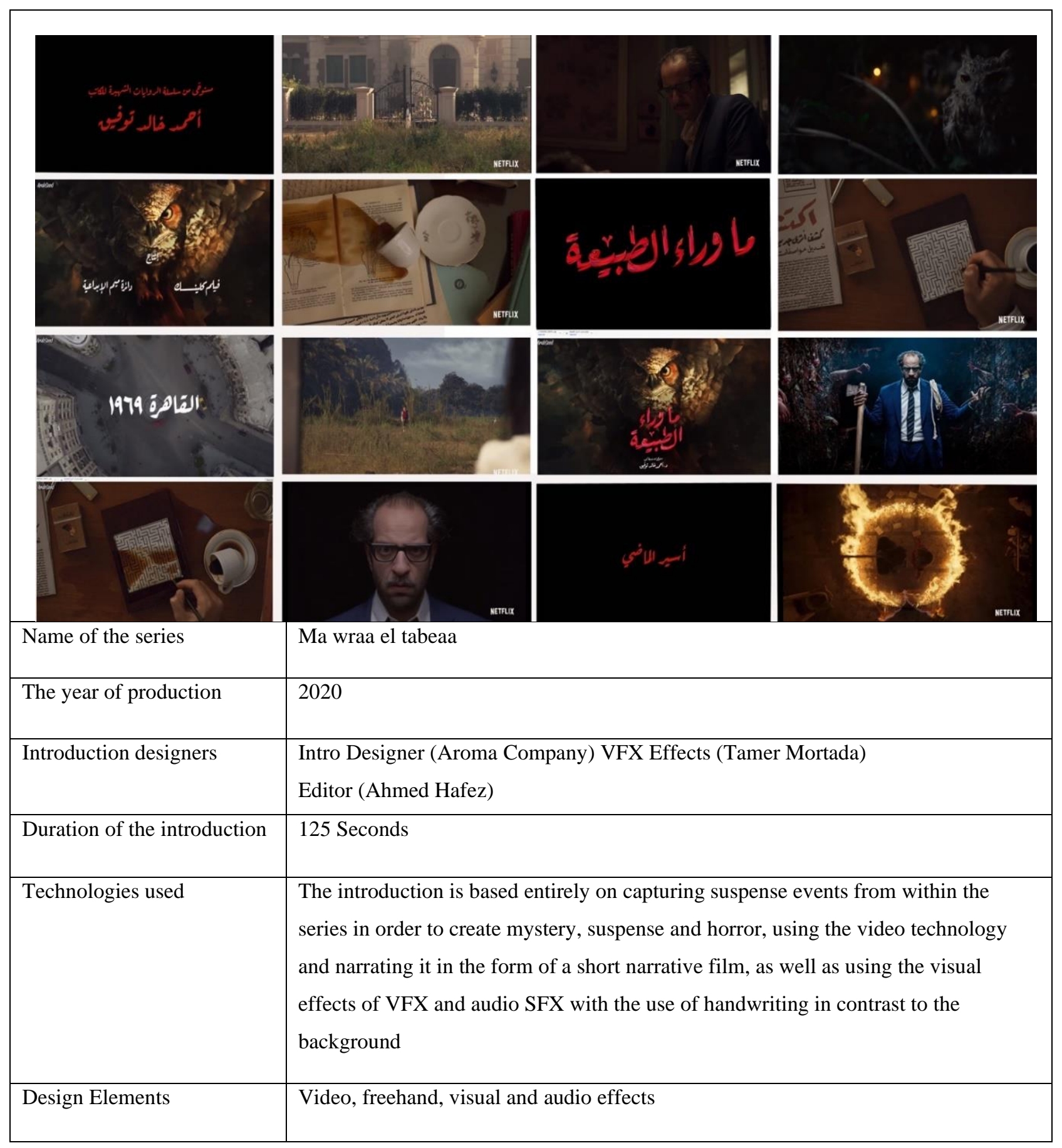

Fig.15 An analytical model from the series introduction (Metaphysics) produced in $2020 \mathrm{AD}$ 


\section{MATERIALS AND METHODS:}

-This study follows the Descriptive Historical method and Analytical Studies of the Introductions to the Egyptian television Series, which are limited Since (1980-2020 AD), spatial Materials limits: TV libraries and available Egyptian channels.

\section{This Study Covered:}

-the Technological sequence to get out of the prevailing stereotypes in TV series introductions.

- Shedding light on the importance of television drama and its introductions in consolidating the concept of the presented visual message.

- The historical development of the intellectual and technical content of the introductions, by analyzing samples of the series introductions.

- Attempt to understand the design methods and intellectual content of the introductions.

\section{RESULTS AND DISCUSSION:}

- From the above, it became clear that drama and its introductions in Egypt have progressed significantly at the technical and technical level, due to the tremendous capabilities provided by digital technology, such as processors, visual effects ... and others.

- The emergence of a type of program known as GUI, which is a Graphic User Interface, which depends on the use of graphics and test menus, and by which any artistic work can be produced from the computer directly on the screen and combined with text and sound, thus entering the computer in the field of television graphics. 


\section{INTERNATIONAL JOURNAL OF MULTIDISCIPLINARY STUDIES IN ART AND \\ TECHNOLOGY}

ISSN: $2735-4342$

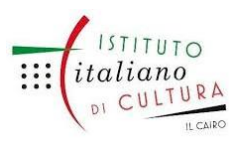

www.egyptfuture.org/ojs/

-Use of graphic and visual methods and processors different from the prevailing before, which appeared heavily at the end of the twentieth century as a result of the development of graphic programs and the development of television output technology associated with the use of computer graphics.

\section{CONCULSION:}

From this study it was found that the appropriateness of the graphic elements and the treatments used in the introductions, that there is a clear role in the interest in the identity of the dramatic work and the dramatic atmosphere that surrounds it, through the realization of the idea. The general purpose of the series, the use of various graphic and visual methods and processors has emerged in abundance at the end of the twentieth century as a result of the development of graphic programs and the development of television production technology accompanying the use of computer graphics.

The graphic designer took into account the technological development in designing introductions and television series, everything related to networks and modern graphic rules in the design processes, and drawing all visual, sound and kinetic effects as a result of the massive torrent of advanced development in graphic design programs on the computer in the design guidance instructions.

\section{References}

- Abou-Lughod, Lila.(2005). Dramas of Nationhood: The politics of television in Egypt, The American University, Cairo Press,P.10.

- Al-Amili, Shatha Hussein Muhammad and the emirate, Zia Muhammad Muhammad Taqi.( 2013). The artistic and aesthetic value of the introduction (the title) in the Iraqi TV drama. The academic, pg. 2013, p. 66, p. 313-334.

-Braha,Yael\&Byrne, Bill.(2013). Creative Motion Graphic Titling with Motion Graphics for Film, Video, and the Web, $1^{\text {st }}$ Edition, Focal Press,Oxford,P.19.

- Fathi, Lia. (2018): The quality of the digital image produced in Egyptian television: between reality and expectations, Department of Photography, Cinema and Television, Faculty of Applied Arts, Damietta University, Journal of Architecture and Arts, Part Two, Issue 12. 


\section{INTERNATIONAL JOURNAL OF MULTIDISCIPLINARY STUDIES IN ART AND TECHNOLOGY}

ISSN: $2735-4342$
VOLUME 4, ISSUE 1, 2021, $27-48$.

www.egyptfuture.org/ojs/

- Inceer, Melis.(2007). An Analysis of The Opening Credit Sequence in Film, CUREJ: College Undergraduate Research Electronic Journal, University of Pennsylvania,P.6,P. 15.

-Inman, Roger \& Smith, Greg.(2006). Television Production Handbook, Retrived from https://tvhandbook.com/Television\%20Production\%20Handbook\%202006.pdf, P.63.

- Kawas, Gamal. (2014), Ganrak in the TV Arabic series A Semiological Study, No 24, Volume A, Algeria,P.1,2 Journal of Human Sciences.

- Marcel, Martin. (2017) The Cinematic Language, T: Saad Mikawy, 1ed.,2017, Arab Pens House for Publishing and Distribution, Cairo.

- Mohamed, Ashraf. (2001). Aesthetic and artistic values of the graphic linking panels between television programs, Master's thesis,P.47-50s, Faculty of Fine Arts, Helwan University, Cairo.

-Saeed, Manar (2002). The Impact of Modern Artistic Styles on Graphic Introductions to Children's Television Programs, PhD Thesis, Faculty of Fine Arts, University of Damascus, Syria,P.108.

- Wang,Y.(2003).Analog TV Systems: Monochrome TV, Polytechnic University, Brooklyn,P.6-7.

- Ibrahim KHALIL, Basma, Khalil, THE INFLUENCE OF REMBRANDT ON COMPOSITION OF IMAGE IN MOVIES, International Journal of Multidisciplinary Studies in Art and Technology, Vol.3, No.2,2020, pp. 7-14.

Received: April 2021

Accepted: June 2021 